\title{
Manuel Gómez-Moreno Martínez: the birth of Islamic Archaeology in Spain*
}

\section{Manuel Gómez-Moreno Martínez: el nacimiento de la Arqueología Islámica en España}

\author{
Fernando Valdés Fernández \\ A Katia Galán, con toda mi amistad
}

Recibido 27/05/2014

Aceptado 01/08/2014

\section{Resumen}

Estudio de la biografía de don Manuel-Gómez Martínez, de sus circunstancias personales, de su obra y del modo que todo eso influyó en el nacimiento de la Arqueología Islámica en España.

Palabras clave: Manuel Gómez-Moreno Martínez- Historiografía de la Arqueología Española- Arqueología IslámicaArqueología Medieval.

\section{Abstract}

A study of Don Manuel Gómez-Moreno Martínez's biography, his personal circumstances, his work and the manner that these aspects influenced the birth of the Islamic Archaeology in Spain.

Keywords: Manuel Gómez-Moreno, Historiography of Spanish Archaeology, Islamic Archaeology, Medieval Archaeology.

In 1898 Spain lost its last remaining overseas colonies - the Philippines, Cuba and Puerto Rico after a long war with its local populations and the United States of America. The event provoked a profound crisis in the Spanish consciousness, without an understanding of which, it is impossible to achieve a knowledgeable history of the country through the twentieth century.

The disappearance of the last remains of the empire left Spain reduced to its own borders, in a similar process to that experienced by modern Turkey a few years later, after the fall of the Ottoman Empire.

There was a very strong reaction to the fall of the empire amongst the Spanish intelligentsia which led to

* English version $\mathrm{M}^{\mathrm{a}}$.José Otero and Douglas Steen, reviewed by Doña Carmen Gomez-Moreno. Fernando the formation of a large group of like-minded intellectuals known as the 'Generación del 98', or Generation of 98 , It was not only a literary movement, also had its scientific aspect. The history of Islamic Archaeology in Spain starts, precisely, with the great intellectual movement which came into being in 1898 .

The foundations of modern Spanish science, especially in the field of the Humanities, are related to the historic period known as the Restoration - of the Bourbon Dynasty after the short lived First Republic (1873-1874). Without the short, but substantial advance undergone by Spain in the third part of the nineteenth century, it is difficult to understand the Generation of 98 .
Valdés Fernández. Departamento de Prehistoria y Arqueología, UAM, fernando.valdes@uam.es 


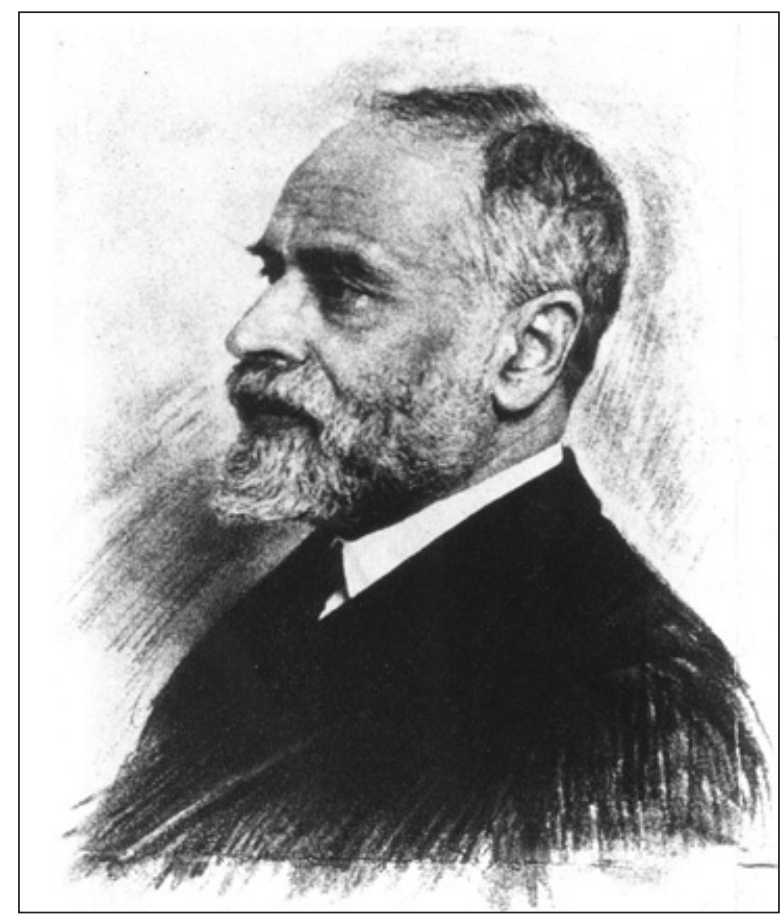

Fig. 1: Manuel Gómez-Moreno in his sixties.

It is within this framework that we should try to include and understand the scientific figure: Manuel Gómez-Moreno. In no small measure his life of Manuel Gómez Moreno and work are sociologically representative of that small Spanish bourgeoisie. The Spanish bourgeoisie, gestated in the first restoration of the Bourbon dynasty, was born and formed around 1898, reached its prime during the 1920's and saw its development brutally interrupted by the Civil War (1936-1939). At that stage, this small group has not yet concluded such cultural regeneration and was just on the verge of consolidating its many important achievements. M. Gómez-Moreno is unique among the figures of his generation in terms of his longevity, which allowed him to bridge, with his principled teachings, the years between 1939 and 1970. A new generation would then take charge, not without difficulties, of the destiny of the country. It is not a coincidence that his great synthesis on the archaeology of al-Andalus (See note 29) was published not when it would have been logical, during the 1930's, but in the 1950's, when almost half a century had passed since the most substantial part of the scientific analyses had been carried out.

Most surprising - and most tragic - is that his conclusions remained invariable, true and undisputed, and not only for their own great value, but due to the inability of subsequent generations to modulate and modify

1 He studied in Granada. Later in 1856, he entered the San Fernando Royal Academy of Fine Arts to complete his education. Between 1878 and 1880, he lived as a scholarship holder in Rome. Finally, he went back to Granada, where he developed his professional activity as a painter, a lecturer in them to conform to the logic of new scientific schools. Follow the steps of your master, but be careful not to tread on his shadow! The great tragedy of GómezMoreno, which has been the great Spanish tragedy of the twentieth century, was the disappearance by death or exile of an entire generation, lost to the collective madness of the Civil War, and the following years under Franco political regime.

For a country like Spain, without a consolidated research structure, or a modern university, that fought painfully to overcome its historic backwardness and tried to create a stable system equivalent to that of the developed countries, the disaster of the war extended beyond the human and material dimension. When the new currents of thought started to bear their best fruit - Gómez-Moreno being an example - the entire life of the country was disrupted. It was necessary to start from scratch. However, the destiny of Spanish science - and that of the entire nation - fell into mediocre, obscurantist and short-sighted hands. Even when these hands were well intentioned and intellectually capable - as, in fact, some were - they were unable to overcome the narrow limits set by a suffocating regime, which lacked patriotism despite its official bombastic statements. Our Fascism did not foster scientific research, not even in a partisan fashion. Science, under no supervision whatsoever, was not one of its priorities. In contrast to many of his contemporary peers, Gómez-Moreno bore witness to this sad process of decay, and acted as a unifying force by virtue of his undeniable moral authority (some of his students became the new authorities) to avoid further damage.

\section{BIOGRAPHY}

Manuel Gómez-Moreno Martínez was born in Granada on the $21^{\text {st }}$ of February of 1870 . He was the eldest son of Manuel Gómez-Moreno González ${ }^{1}$, a painter and a scholar from Granada, and of Dolores Martínez Almirón, also from Granada.

He graduated from the "Colegio de los Padres Escolapios" and started and finished his Arts studies (1886-1889) in the University of Granada, obtaining its maximum qualifications. There was nothing to suggest, at least in principle, that he was anything other than the product of a cultured middle-class family with solid Catholic beliefs, living frugally in a distant provincial capital, isolated from the cultural and decision- making centres of the country.

the School of Arts and Crafts, and as an Art historian. He was co-founder of the Artistic and Literary Centre of Granada, which used to publish a bulletin including many articles on the History of Art and Archaeology of Granada. 


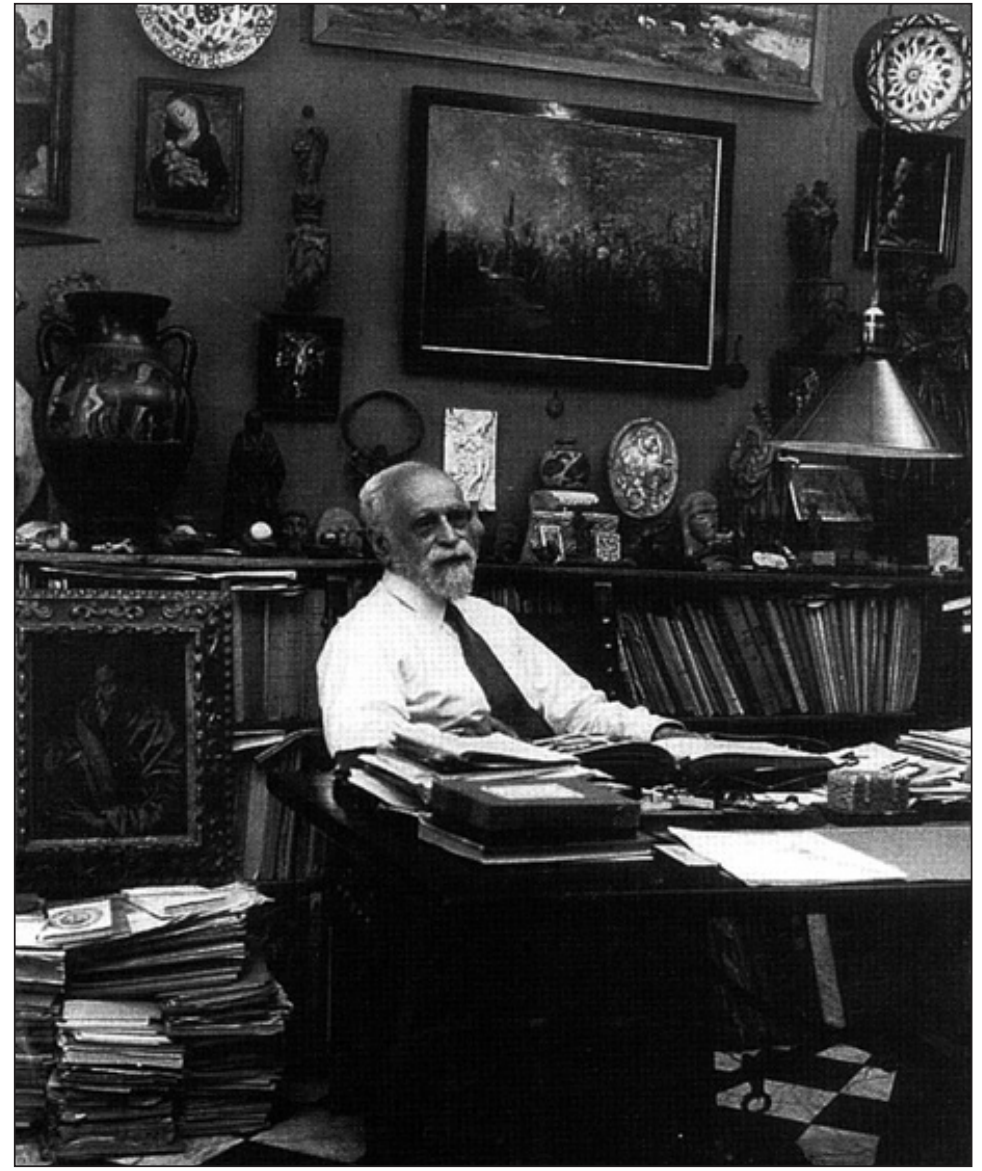

Fig. 2: Manuel Gómez-Moreno at ninety

It's worth mentioning however, an occurrence that appears to have had a strong effect on the life of the young Manuel: his father's stay in Rome, accompanied by all the family, for the period between 1878 and 1880 .

In the Italian capital, the Gómez-Moreno family maintained close contact with the colony of Spanish artists living there, who were also scholarship holders, - amongst them Alejandro Ferrant, Francisco Pradilla, José Casado del Alisal, José García Ramos, etc. - the majority of whom, in the fullness of time, would become important Spanish artistic figures of the period. Gómez-Moreno, in spite of his youth, used to accompany his father on his visits, to museums, churches and monuments. He also joined Alejandro Ferrant and the archaeologist Orazio Marucchi, with whom he toured the Rome of the basilicas and catacombs. This stay in the Italian capital made a strong impression on the child that he would maintain always, and was reinforced and fermented by the artistic atmosphere in which he lived.

2 This short publication is, in my opinion, the first work of Spanish modern archaeology. It contains a systematic study of the old Arab city, located in the Atarfe farm - nowadays, a district in Granada - including the study of documentary
After finishing his university studies, he began to collaborate with his father in various of his research works. Amongst other projects, two are worth highlighting: the opusculum entitled Medina Elvira ${ }^{2}$ and Guía de Granada (Gómez-Moreno González, 1892). In the second, Guía de Granada, the son made a very substantial contribution to the work, but he did not want to take credit for it out of respect for his father. All of the drawings of the first work, and possibly more, were also the work of the young researcher.

In 1897, the young Gómez-Moreno published a work dedicated to the discoveries made in Martos (Jaén) (Gómez-Moreno, 1897), which gave rise to a playful anecdote narrated in detail by María Elena GómezMoreno: "When the great epigraphist Emilio Hübner, at the suggestion of Rodríguez de Berlanga, asked Gómez-Moreno for information on inscriptions from Granada for his monumental 'Corpus', it was the son who gave it to him. Hübner went to Granada shortly afterwards and, when presented to his young collaborator asked to see his father; to his great surprise he learnt that it was not the father but the son with whom he had corresponded. He helped him in his work, and at his side he learnt epigraphy. Their friendship and collaboration, which had had such fortuitous origins, lasted until the death of Hübner in 1904." (Gómez-Moreno, 1995: 46).

In 1898, the young Manuel, who until then had been living from his classes in the Sacromonte Seminar, and in the School of Arts and Crafts in Granada, decided to look for a more solid position, so as not to have to depend economically on his family. This same year, a good opportunity arose through the creation of a chair of History of Art in the Central School of Arts and Crafts in Madrid, a position which would be contested by public examination. Manuel moved to the capital of the kingdom to prepare for the exams for the post, and to wait for the time, which was said to be imminent, in which these exams would take place.

In Madrid, he got in touch with an old friend of the family, the painter Alejandro Ferrant, who like his father, had been a scholarship holder in Rome, and member of the San Fernando Royal Academy of Fine Arts. He, in turn, introduced him to another illustrious person from Granada, Juan Facundo Riaño. The friendship with this man and his family

sources, an account of the excavations on the site, a systematic catalogue of the findings - with the description and a drawing of each piece - and a substantial chapter of conclusions (Gómez-Moreno González, 1888). 
proved to be decisive for the career and destiny of the future scientist.

J.F. Riaño was professor of Arabic in the University of Granada, but at the time of meeting the young Gómez-Moreno, he was professor of History of Art in the Diplomatic School ${ }^{3}$. He was the son-in-law and past pupil of Pascual de Gayangos, the famous Arab authority and bibliophile, who had been educated in France and had spent much of his time living in London ${ }^{4}$. J.F. Riaño proved to be a seminal contact for the young Gómez-Moreno. Between them they established a great personal friendship and while Riaño divined intellectual qualities worthy of being fostered in the research apprentice, for Gómez-Moreno, Riaño was an essential contact with the most outstanding and progressive Spanish intelligentsia of the time. It would be difficult to understand the intellectual personality of our researcher without understanding his relationship with this advanced intellectual circle, who were the first to react in the face of the disaster of 1898 .

However, the terms of the public exam were never met. The post was never contested and our specialist had to survive thanks to the work entrusted to him compiling successive catalogues of monuments, and any other temporary work. He maintained his residency in Madrid while keeping an eye on Granada, in the hope that an opportunity would finally arise.

In 1901 Gómez-Moreno began his relationship with Guillermo de Osma, a personality with great influence in Spain at the time ${ }^{5}$. Through his father in law, De Osma had become a lover of antiques, especially ceramics, compiling a magnificent collection in his residency in Fortuny Street, in Madrid. With time, this collection would become the famous Museum 'Valencia de Don Juan'. The relationship between the

3 He was quite a character in Spanish cultural circles at the time. In 1880, he started his political career in the ranks of the liberal party, which would lead him to hold several outstanding posts. He was State Counsellor, Deputy, Senator for Granada, member of the Academy of History, and Director of the San Fernando Royal Academy of Fine Arts. He founded the Museum of Artistic Reproductions, thanks to his numerous international contacts, and was a member of the German Archaeological Institute. He was also a good friend of Francisco Giner de los Ríos and was closely linked to the Institución Libre de Enseñanza The Institución Libre de Enseñanza had been founded by the latter in 1878 with the objective of trying to renew - on the fringe of official institutions - the paralysed Spanish pedagogic scene from a modern perspective, free of dogmatism and where "education" was to take priority over mere "training".

4 He would later become the Director of the National Library in Madrid, General Director for Public Education and a member of the Royal Academy of History. He was one of the most representative characters of the Spanish intelligentsia at the time. A liberal, familiar with the latest European intellectual trends, he turned - in María Elena Gómez-Moreno's words - into “...the entertainer of a whole archaeologist and the Count, famous for his bad temper, was always cordial. He was soon invited to the gatherings, only for men, that were organised every Sunday in the residence of de Osma. When he died, a foundation was created to oversee the institute and museum established by him. The Chancellor of Oxford University, among others, belonged to this foundation. When the first director, the numismatist Antonio Vives, disappeared, Gómez-Moreno became the new director of the Institute in 1925. This allowed him to come into contact with the world of antiquarians and to add new pieces to the already extraordinary collection.

On the $29^{\text {th }}$ of May 1903, the young scientist married Elena Rodríguez-Bolívar, four years his junior, and daughter of an old friend of his father, Manuel Rodríguez Bolívar, who, as President of the Council of Granada, had helped his father to secure his scholarship to visit Rome. The wedding took place in Granada $^{6}$. Elena was a wonderful pianist, though not to a professional level. They went on to have seven children, three boys - Manuel, José and Eugenio - and four girls - María Elena, Nati, María Teresa and Carmen. The two eldest sons died in childhood and the third - Eugenio - perished in the defence of Madrid, during the Civil War - December 1938.

Following an idea outlined by Riaño, initiated by F. Giner de los Ríos, and through the dedicated work of José Castillejo, the Board for the Enlargement of Scientific Studies and Research, was set up in 1907. Castillejo was made Secretary General of the organisation and remained so until his disappearance in 1936. The organisation's constituent parts included, amongst others, the Centre of Historical Studies, which was itself sub-divided into various sections: History, under the charge of E. Hinojosa and R. Menéndez-Pidal; Arabic,

group of pro-European intellectuals, who were determined to incorporate Spain into Europe - Spain, which, with more than a century of military and political problems, exacerbated by the effects of the black 1898, had been forced into dangerous cultural isolation” (Gómez-Moreno, 1995: 78).

5 Guillermo Joaquín de Osma y Scull was born in 1853. His mother was English. He studied in the Sorbonne and Oxford, and joined the diplomatic corps. He was a Diputado a Cortes and held top posts in the Spanish Administration. He married Adela Crooke, only child of Count de Valencia de Don Juan. He was also a diplomat and archaeologist, who would become Director of the Royal Museum of Arms in Madrid, a member of the Academy of History and an important collector.

6 Elena was an efficient collaborator to Gómez-Moreno in his field work. She worked with him in the completion of the Catálogo Monumental de Zamora (Gómez-Moreno, 1927). She was the first to hold in her hands the ivory casket of the Zamora cathedral - which today can be seen in the National Archaeological Museum in Madrid -, a Cordovan work dating back to the second half of the tenth century, dedicated to Sub, the wife of Caliph al-Hakam II and mother to Hisham II. 
with J. Ribera and M. Asín, and Art, with E. Tormo. In 1910, Gómez -Moreno was asked to take charge of the Archaeology Section which he gleefully accepted. He began his courses and activities the following year, in 1911. On the $27^{\text {th }}$ of June, 1909, Gómez -Moreno presented, reluctantly, his doctoral thesis. Its title was $D e$ Arqueología Arábiga (On Arab Archaeology), for which he achieved maximum marks.

The way was paved for him to enter the Central University. In 1911, a chair in Arab Archaeology was created especially for Gómez-Moreno. He refused to take up the chair and insisted that the position be contested publicly. After various vicissitudes in the formation of the examination tribunal, the exam finally took place between the $21^{\text {st }}$ of May and the $2^{\text {nd }}$ of June 1913. Gómez-Moreno obtained his post without any problem.

On the $28^{\text {th }}$ of January, 1930 , the dictator General Primo de Rivera resigned. General Dámaso Berenguer was called by Alfonso XIII to succeed Primo de Rivera as Prime Minister. Dámaso Berenguer formed a government which included the Duke of Alba as Minister of State, and Elías Tormo as Minister for Public Education. The latter, a scholar, had already participated in political activities - firstly as a Senator, and later as Professor of the Central University. Tormo asked Gómez-Moreno, his old colleague from the Centre of Historical Studies, to take up the position of Director General of Fine Arts?

Gómez-Moreno did not last long in the post. He resigned in December of the same year, tired of fighting against administrative and other difficulties that he could never overcome, and seeing the continuum of his scientific work interrupted. However, in the field of archaeology and the conservation of monuments, his work was extraordinarily successful. The Monumental Zones created under his administration were dedicated to the protection and conservation of architectural monuments. Another enormous administrative advance was the initiation of records to declare as national monuments more than six hundred buildings and archaeological sites which, from then on, would be legally protected from destruction or arbitrary intervention. However, the implementation of all this was delayed, and only became law under the the Second Republic's administration which took the credit for it $^{8}$.

7 "Elías arrived at Manuel's home on the morning of February the $1^{\text {st }}$. The latter's working room adjoined the study where Elena [Manuel's wife] was and from where she could hear part of the conversation through the door, due to the low and powerful voice that Elías had, and to Manuel's angry shouting, who was flatly refusing the proposal. Elías, without losing his temper, let him protest until, very calmly, he took from his briefcase the appointment that had just been signed by the King." Gómez-Moreno 1995:388.

8 In fact, there were 642, although all the goods that had
In fact, it happened during the period in which GómezMoreno was Director General, and had the political situation been different, the credit should have been his.

Perhaps the most spectacular action overseen by Gómez-Moreno in order to protect a monument was the removal of the church of San Pedro de la Nave in Zamora. The little church, dated by Gómez-Moreno as being from the Visigothic era (Gómez-Moreno, 1906 a), was under threat due to the construction of the reservoir of Ricobayo. When agreement was reached between the Ministry and the construction company, the little building was dismantled, stone by stone, and moved a short distance out of the reach of the reservoir waters. The work was neatly carried out by the architect Alejandro Ferrant. The whole building was removed, with the exception of the foundations, and reconstructed adding nothing which had not been originally in the primitive church ${ }^{9}$.

\section{RETIREMENT}

Gómez - Moreno's career in the University ended abruptly, almost in keeping with the dramatically changing times in which he lived .

The Universidad Central de Madrid, which was decaying and scattered throughout various buildings in the city, did not meet the basic requirements, in terms of its facilities, for a University. In tackling this problem, firstly under the sponsorship of King Alfonso XIII, and later under the Second Republic, the so-called Ciudad Universitaria was created. It was situated in the north-east of the capital. The new complex was built in the form of a series of spacious buildings, which housed the various faculties and corresponding services in a single urban area.

The Filosofía y Letras Faculty began its courses shortly after having moved, with many difficulties resulting from the infrastructure and teachingaid material shortages. Gómez-Moreno had given his classes, up till then, in the class-rooms of the Centre of Historical Studies, where he had access to the photographic archives, projectors, etc. He now had to come to terms, very reluctantly, to the new situation during the course of the year 1934. The persistence of the teaching problems led him to request his retirement in 1935, five years before the legal age. This was the end of his teaching career.

belonged to the Crown until then were also included in the same decree. Decree of 3 June, 1931, published on 4 June, 1931 in the Gaceta de Madrid.

9 "Copious graphic documentation and the letters, wherein Alejandro gave an account of the progress of the works, allow us to understand the process; however, nothing was ever published, since every attempt to make him write and publish a study about it ran up against his apathy as a writer, so much in contrast to his endless activity as an architect" (Gómez-Moreno, 1995: 391). 
The retirement from University lecturing of the archaeologist did not imply, apparently, a qualitative change for the worse in the study of Spanish Islamic archaeology, and of the History of Art in general. Even though he no longer gave classes, he continued to exercise his peerless teaching from the office of his house, and from his post in the Academies, in the Institute 'Valencia de Don Juan', etc. Nevertheless, his departure would prove to be disastrous. War and its consequences prevented the appointment of a quick replacement to his former chair in the University. Some years later, when the position had been filled, the course title was changed from Arab Archaeology to Medieval Art. Not until the 1980 's would there be a post specifically dedicated to the study of Arab archaeology in any Spanish university. Before the 1980's only History of Art in the most traditional sense, and devoid of any Archaeological input, its methods and techniques, was taught. Despite this, outside of Spain, and thanks in part to Prehistoric studies, Archaeology had greatly evolved after the Second World War. This was wonderfully alluded to in a letter to the El País newspaper on the $18^{\text {th }}$ of January 1984: "He was [Manuel Gómez-Moreno] Head of the Section for the Centre of Historical Studies and the chair of Arab Art and Archaeology was created for him in the Universidad Central. But in 1934 [...] the University demanded that Gómez-Moreno along with his students, carry out research in the faculty (where he did not have any teaching material) as opposed to the Centre of Historical Studies (where he had the library, photographic material and classrooms). Faced with this impossible situation, Gómez-Moreno took early retirement in 1935, and continued his research in the Centre, but was forced to abandon his hopes of founding a school. With his death in 1970 the study of Muslim Art in Spain disappeared, and since then, the foreign institutes have taken the initiative in this field. The Mosque in Cordova, the Aljafería in Saragossa, the Cristo de la Luz in Toledo, are all published by the German Archaeological Institute, in German, to the eternal shame of the Spanish and the good fortune of the Germans" ${ }^{10}$.

It could be said that the departure of GómezMoreno from his chair, heralded the simultaneous departure of the study of Islamic Archaeology from the university classrooms of Spain. What little study that was carried out from the time of his departure, up until very recently, - over half a century! - was due to meritorious endeavours on the part of the Consejo Superior de Investigaciones Cientificas, the archaeological museums, some local institutions, and various cura-

10 The article was signed by Rafael Lapesa and Pedro Laín Entralgo and the already deceased Dámaso Alonso, Antonio Tovar, Jimena Menéndez-Pidal, Emilio García Gómez, Julio tors. In any case these were individual actions with no support from any University Institutes. His scientific successors were his grandsons - almost his greatgrandsons -, and not his sons as would have been more natural. Is it surprising then, the conceptual backwardness that our discipline has suffered, despite the renaissance which has taken place over the last number of years?

\section{The Personality of Manuel Gómez-Moreno IDEOLOGICAL PROFILE}

One could ask what the reasons are for GómezMoreno passing so unnoticed by Spanish intellectual circles in the 1980's. This, in spite of his outstanding contribution to the academic, scientific, and administrative fields, and most of all, in spite of his undisputed mastery in this area for over seventy years. As mentioned earlier, he strongly denied belonging to the Generación del 98, but his inclusion in this group is undeniable. However his way of sharing their restlessness and their regenerative aspirations was not channelled through literature, but through research and teaching, - disciplines less luminous and exposed to public scrutiny, but no less decisive or far-reaching than others like literature, for the development of society.

Gómez-Moreno was not a revolutionary in the commonly perceived sense of the word. Never in the course of his scientific work, at least apparently, did he challenge or subvert the widely held theories accepted by all. Equally, his private life was never anything less than normal for a middle-class person with intellectual interests, but without any great fortune, save that which he had been able to make through his own efforts which enabled him to continue his scientific work and support his family. In a classist society, intellectually underdeveloped, and one with a scant regard for culture in general, asas Spain was at the time and, apart from nuances, still is - much of GómezMoreno's behaviour is perfectly understandable.

On the contrary, it would have been very strange for a person with his background, training, friends and interests to have been a revolutionary. The majority of his contemporaries - some of them very famous for their allegedly radical attitudes - were not revolutionaries either. This does not mean, however, that GómezMoreno was devoid of political interest, or that he was indifferent to the situation in the Spain in which he happened to live. Nobody has portrayed better, his moods in critical phases of his life, and the life of Spanish society, than his daughter María Elena. One of

Caro Baroja, María Elena Gómez-Moreno, as well as the Nobel laureate Vicente Aleixandre. 
such passages is related to the transition from the Monarchy to the Republic, some months after having resigned as the Director General of Fine Arts: "GómezMoreno did not consider himself a republican, but neither did he feel linked to a monarchy that complied with a dictatorship. A sense of rediscovered liberty was being enjoyed by the youth of the day. The people were willing to grant a margin of trust to the new order in which the most outstanding figures of the Spanish intelligentsia were actively involved. Moreover, against all the odds, the transition from a discredited monarchy to a hopeful Republic, had taken place without any bloodshed”. (Gómez-Moreno, 1995: 394).

However, the situation degenerated into turmoil and destruction as a result of which part of our artistic heritage was endangered or simply destroyed. GómezMoreno was lecturing at the Summer University of Santander and he returned to Madrid to became directly involved in the fight for the protection of this cultural legacy that belonged to society as a whole. He always did this in his own name and without any fuss. Without the protection of any post, any political membership card, or as a member of any lobby group, he prevented, on his own, and at risk to his physical well-being, the attempted arson of the priceless library of the Jesuit convent of Chamartín, in Madrid, when a furious mob were already looting the building (Gómez-Moreno, 1995: 394-395).

When the Civil War started, in July 1936, GómezMoreno became a member of the Board for Seizure, Rescue and Cataloguing of Artistic Treasury. This Board worked in Madrid in order to protect - also from its owners - the artistic heritage that remained whilst the city was under siege from rebel troops, and while the government, accompanied by many revolutionary intellectuals, had withdrawn to Valencia ${ }^{11}$. Before the conflict had begun, Gómez-Moreno had already

11 It was chaired by the architect Roberto Hernández Balbuena and consisted of, amongst others, Angel and Alejandro Frerrant, Gómez-Moreno, and the professors - and former pupils of Gómez-Moreno - Cayetano de Mergelina and Diego Angulo. A group of students of Architecture and Fine Arts also co-operated in the effort, amongst them, it is worth mentioning María Elena and Nati Gómez-Moreno, as well as Fernando Chueca. Two of them: Joaquín Pérez Villanueva and Gratiniano Nieto Gallo, young pupils of Mergelina, were undercover falangists. They became professors and both of them would be appointed, in time, Director Generals of Fine Arts. The latter ended up being a pupil of Gómez-Moreno and followed up his disrupted administrative and university work, with different means and under different circumstances (Álvarez Lopera, 1982).

12 One of the results of his works, which made possible the recovery and restoration of the Holy Ark with all its contents, was the article Gómez-Moreno (1934 a).

13 "In the middle of this chaos [referring to that which prevailed in Madrid at the beginning of the Civil War, in the travelled with the architect Alejandro Ferrant to Oviedo to save the remains of the Cámara Santa (Holy Chamber) in the cathedral, blown up by rebels in October 1934, in the so-called Asturian Revolution ${ }^{12}$. However, he could not prevent the looting of paintings from the Prado Museum, and also in his absence, the splendid collection of Medieval Art treasured by the 'Valencia de Don Juan' Foundation was threatened by a similar disaster ${ }^{13}$. Other than that, Gómez-Moreno remained in Madrid with his family, undergoing the same hardships as the rest of the population of the besieged city, and sharing like many of them, the painful experience of losing his youngest child, Eugenio, under unknown circumstances in the front line.

It cannot be said therefore, that Gómez-Moreno was an enemy of the republican regime. He was not a loyal supporter of any specific political stance. He suffered the same hardships as the great majority of the Spanish people and did what he could to minimise the dimensions of the tragedy.

In spite of everything he could not escape the 'justice' of the victors. The day after their entry into Madrid, his office in the Centre of Historical Studies was searched and looted, manu militari, by a colleague, who went on to be a professor of Prehistoric Studies and History of Primitive Man in the Universidad Central de Madrid. Things could have been worse. He was about to be held responsible for not having moved to the rebel held zone during the war ${ }^{14}$. In short, his only crime was his independence of thought. From his own conservative ideological perspective, he had not committed himself to either side. He did what he considered fair and wise, and helped his country as best as he could, knowing that both sides were committing outrages. Nevertheless, there were many people, amongst them his former students, who tried honourably to curtail the scope of the tragedy. Would anybody, therefore,

summer of 1936], Anastasio, the caretaker of the Institute Valencia de Don Juan, phoned to say that armed militiamen were prowling around the house and that they feared their assault. In the absence of my father and the Chairman of the Board, they were scared and did not know what to do. Luckily, I remembered having heard that in the founding statutes of the Institute, Osma had established that should the State try to intervene or the Institute be at risk, the Oxford University would take over the building, since its Chancellor was a member of the Board. Bearing this in mind, I told Anastasio to hoist the Union Jack on the balcony and to inform the British Embassy at once. Shortly afterwards, an official from the Embassy placed a stamped notice on the door, and with the flag and the notice, the danger passed" (Gómez-Moreno, 1995: 468).

14 “Gómez-Moreno's absence from the nationalist area had already been condemned, but he was defended by Cardinal Gomá, Archibishop of Toledo, with whom he had had no relation whatsoever" (Gómez-Moreno, 1995: 483). 
be surprised at how unheralded, outside of a small circle, Manuel Gómez-Moreno remained, even after the Spanish political transition to a democratic system?

\section{UNIVERSITY CONTRIBUTION}

His contribution as a university professor, and the influence that he had in the birth and development of Archaeology and the History of Art in general, can be easily deduced by a study of the list of his former students, who, either attended his classes or benefited from his generosity when he had retired. Amongst his former students, there are no fewer than twenty professors ${ }^{15}$, four General Directors of Fine Arts ${ }^{16}$, and a large number of museum curators and Heads of Department in secondary schools ${ }^{17}$. Paradoxically, in spite of his contribution as a university professor, he did not have a successor to his chair of Arab Archaeology, the first of its type in Spain and perhaps in Europe, which as mentioned earlier, had its title and content changed.

Furthermore, he was one of the founders of the Centre of Historical Studies, a precedent to the historical section of the Consejo Superior de Investigaciones Científicas, which has recovered once more, its former title. From this institution, in collaboration with E. Tormo, they produced the magazine Archivo Español de Arte y Arqueología.

\section{Scientific Contribution}

Without considering the importance of M. GómezMoreno in other scientific fields, such as Prehistoric Studies, Medieval History, History of Art, Epigraphy, Numismatics, or Philology, we need to consider his real contribution to our knowledge of life and art in $\mathrm{Al}$ Andalus.

Undoubtedly, Gómez-Moreno is a pioneer of systematic archaeological and monumental prospection in Spain, and thanks to this system, he was the first to catalogue the church of San Pedro de la Nave (Zamora) (Gómez-Moreno, 1906 a). Moreover, he discovered and defined the so-called 'Mozarabic style' (Gómez-Moreno, 1909, 1913 b and 1919), the most essential chapter of the Spanish early medieval Art since it includes the late Roman architectonic tradition, as it existed and had developed in the pre-Islamic period, and the new 'orientalising' decorative trends of Byzantine and Sassanian origins emanating from the Umayyad artistic centre of Cordova. Furthermore, he

15 Diego Angulo Íñiguez (Director of the Prado Museum), Antonio Beltrán Martínez, José Camón Aznar, Julio Caro Baroja, Juan de Mata Carriazo, Fernando Chueca Goitia, Antonio Floriano Cumbreño, Antonio García Bellido, Enrique Lafuente Ferrari, José Ferrándiz Torres, Cayetano de Mergelina, Joaquín María de Navascués, José Manuel Pita Andrade (Director of the Prado Museum), Javier de Salas Bosch (Director of the Prado Museum), Javier Sánchez Cantón (Director of the Prado Museum), Manuel de Terán was the co-author, along with his father, of the first modern archaeological publication printed in Spain (Gómez-Moreno González, 1888).

Gómez-Moreno was the first to systemise Andalusí art and archaeology, although his great synthesis ${ }^{18}$ was only published several years after he had already explained it in his university classes and in his many lectures. Partial synthesis of certain aspects of the Andalusí or post-Andalusí material culture had already seen the light (Gómez-Moreno, 1914, 1912, 1922 , $1924 \mathrm{a}$ and $1924 \mathrm{~b}$ ), and he contributed substantial new data to what was already known in other specific fields: ceramics (Gómez-Moreno, 1940. Cf. previous note), ivory (Gómez-Moreno, 1911), stone sculpture (Gómez-Moreno, 1941a), jewellery (Gómez-Moreno, 1943c), textiles (Gómez-Moreno, 1946c, 1947b and 1948), and certain lesser known Islamic monuments (Gómez-Moreno, 1916, 1945a, and 1947a). However, the main body of his written work, in relation to the number of his projects, was dedicated to his native city of Granada, from which he could never separate himself intellectually or emotionally. Granada, above all other cities, was the focus of the majority of his first publications and also that of some of his last (See final bibliography). Thanks to his efforts, our knowledge of the Islamic Granada, and - though it is not the object of our study -, post-Islamic Granada is divided into two perfectly defined periods.

Even at an anecdotal level, his contribution to archaeological terminology should not be forgotten. We are indebted to him for terms such as 'cuerda seca', 'verdugones', 'Salon Rico', etc. Many of these terms are products, sometimes very idiosyncratic, of his way of speaking and his Andalusian wit, and as such, are not easily understood by many native Spanish speakers, let alone non-Spanish speakers for whom it would be impossible.

Gómez-Moreno was, in conceptual terms, the first to recognise the great influence that Eastern Mediterranean culture had on the Andalusí. No small achievement, when one takes into account the extremely powerful force, even today, of 'HispanoCentralism' applied to the interpretation of the cultural world of al-Andalus. However, even allowing for his enlightened views in this regard, he could not align the theory of a traditional indigenous peninsula with the Arab cultural contribution, and this constituted one of his most remarkable contradictions.

Álvarez, Leopoldo Torres Balbás, Antonio Tovar Llorente.

16 Antonio Gallego Burín, Gratiniano Nieto Gallo, Ricardo de Orueta, Joaquín Pérez-Villanueva.

17 Teresa de Andrés, Cristina de Arteaga, Jesús Bermúdez Pareja, Emilio Camps, Manuel Casamar, Manuela Churruca, Jesús Domínguez Bordona, Juan Antonio Gaya, Rafael Laínez, Felipe Mateu i Llopis and José Moreno Villa.

18 Gómez-Moreno (1951c) An advance of which had already been published in 1932, $1961 \mathrm{~b}$. 
Gómez-Moreno had studied Arabic in Granada under F.J. Simonet, the leading exponent of Spanish traditionalism as applied to the study of Andalusí Islam. In fact his most celebrated work (Simonet, 1873/1903), which Gómez-Moreno himself prepared for publication, has a very clear objective, stated at the beginning by the author: "It is our purpose to record the story of those Spaniards who, though subjugated by the Moors, but not without honourable pacts and capitulations, maintained, constantly, and throughout many centuries, the religion, the national spirit and the culture of the old Christian Roman-Visigothic Spain. They endured with forbearance many hardships, persecutions, and calamities, persevering to reap the noble laurels and palms accruing to heroes, to doctors and martyrs. They contributed through their efforts and knowledge, to the restoration and progress of the new Spain and they lent their name to the ancient and venerable Gothic-Hispano-Mozarabic rite" (Simonet, 1873/1903: I).

According to this point of view, which is still accepted by some in our field, the Islamic culture in alAndalus was a mere blemish on the Christian society, which remained the dominant one, with their way of life only superficially affected by Arab culture. As such, every great achievement was seen from the perspective of the indigenous Roman-Christian tradition. It was nothing more, and nothing less than the propagation of the absurd myth of the Eternal Spain.

Gómez-Moreno was not capable of overcoming this opinion, which went unchallenged and was commonly accepted amongst intellectual circles at the end of the nineteenth century, and for at least the first seventy years of the twentieth century. Traces of this mindset can be found in many of his works ${ }^{19}$. Neither could he deny the Castilian influences on his thinking, which is understandable for one of his generation ${ }^{20}$.

The work which best betrays the traditionalist influence of Simonet is the famous Excursión a través del Arco de Herradura (Gómez-Moreno, 1906). In this work he reviews the historic and geographic path followed by the famous horseshoe arch, from the East to the West, underlining its Spanish manifestations from the indigenous pre-Roman world, to the late Roman period, immediately before the Islamic conquest. The reappearance of this architectural element in the

19 To give an example, when referring to the language spoken by the Andalusí society, he says: "a further difference [between Muslims and Christians] which was thought to be, up till today, a profound one was language; but we already [...] know that Arabic was for our Muslims no more and no less than Latin for Christians, an erudite language" (Gómez-Moreno, 1970: 69).

20 "There must be something in the Spanish national consciousness that is true when it is so harshly criticised, when so many people strive to minimise it, and when the ones who own it and exploit it care so little about its links. That "something" first stage of the Great Mosque in Cordova and its proven existence in the last constructive stages of the Gothic kingdom of Toledo, led him to conclude the following: "Our arch is not characteristic of any architectural style in the East, neither is it unique, with the exception of some valleys in Capadocia [...] with regard to Spain, there are more indications of the existence of an architectural stage between the Roman decay and the Arab invasion, whose main feature was our arch. Perhaps this is because some of the main cities of the time, Mérida and Seville, for example, made this arch fashionable, borrowing it from the vulgar indigenous art, during the prosperous Constantinian era [...]. Afterwards, the assault by the army of the Muslim Berbers, led by Muza, against the Visigothic government, signalled the abrupt end of our Art. The new law forbade the construction and restoration of churches. Neither were they particularly lavish with their Mosques, bearing in mind how mean the primitive people of the East were. Therefore, when Cordova wanted to have a Mosque it is hardly surprising that they seized half of the cathedral, precious building that it was [...] . Thus, Andalusian Christian art began to serve the Muslims and the transformation of the cathedral into a Mosque resulted in an admirable building which, far from suffering the bad fortune of other buildings - reconstructed once, twice or even more times -, set the standard for the Spanish-Muslim Architecture. For a people to have an art form, it is enough to cherish just one work. The Cordovan Great Mosque represented for the Andalusian Muslims and the Berbers, their symbol of uniqueness with respect to the East, though for the Christians it was a painful, but nevertheless cherished, memory. It is hardly surprising, then, that if the horseshoe arch abounded there, that it prevailed and propagated" (Gómez-Moreno, 1970: 389). In short, the horseshoe arch, as we see it in Cordova, owes nothing to the Arabs. It is an adaptation of a local form recuperated from the Late Antiquity which existed in the pre-Islamic Cordova. The entire piece conforms to the indigenous view, in the most traditional line of Spanish Historiography. In spite of everything, his nationalist enthusiasm was understandable in 1906, when the most important works dedicated to Islamic archaeology and art were yet to be written. The definition of Eastern Umayyad

is the supremacy of Castile; the historical bond that a part of Spain arrogates to itself and denies to the rest of the Peninsula; the confidence with which a peasant from the Plateau of Castile, with his hand on the tiller of the plough, considers himself the arbiter of Spanish life, and without boasting, without distrust, unaware of any novelty, passion or interest in the world; he maintains the national unity against regions that judge themselves superior to Castile and which have proved to be so" (Gómez-Moreno, 1970: 83). 
art was still a problem. The Byzantine basilicas of northern Syria had not been systematically prospected or studied, nor did we know anything about the classic art of the Abbasids, since the excavations in the palatine city of Samarra (Iraq) were still to be carried out.

Gómez-Moreno's stance, though still not clearly stated, changed with the passage of time, becoming more pro-Oriental and moving away from his initial view. Evidence exists to support this view. We could mention several examples, not only in reference to Islamic, but also in late Romanesque and early Gothic $\operatorname{art}^{21}$, wherein he tries to rationalise the evident arrival of very early Eastern influences, without abandoning his former parochial thesis. His final position is defined in his late, great, synthesis, published as Volume III of the work Ars Hispaniae. In the prologue he states bluntly: "From the cave of Menga until today, Spain has not created a building [speaking about the Great Mosque of Cordova] comparable in originality and richness, as a model of what did not reach us from Europe but, on the contrary, contributed to the Spanish expansion through the Mediterranean. This bears witness to what has been mentioned before about the essentially evolutionary nature of our 'arabised' art as opposed to the European fluctuations.

This reacting within itself, persistent in our Arab art, revives with spaced out contributions of orientalism throughout its evolution. In this way, it received the Mesopotamian decorations in stucco; from Byzantium, a growing taste for animal and, even, human representation, only annulled by the Berber fanaticism; from Mesopotamia also, exquisite brick bonding and the inspiration of the interlaced designs, later, geometrically developed here; the Byzantine technique of glazing was learnt, and complemented with golden Mesopotamian earthenware, reincarnating everything so as to make it feel our own" (Gómez-Moreno, 1951: 17). In other words, the Umayyad art of al-Andalus is the product, above all, of the indigenous genius and its evident novelties are the result of "spaced out contributions of orientalism throughout its evolution". Here, the synthesis is achieved between his original 'Hispano-Centric' ideology and that sentiment hinted at throughout his career, that the art of al-Andalus was

21 "It seems to be a fact that throughout the first half of the twelfth century, our Art survived on the remains of the previous one. Political circumstances did not favour anything else, in open contrast to foreign Christian progress, the Crusades and the Norman conquests in the Mediterranean. All these attracted Oriental trends to the West, reflected in the taste for the splendour and for Byzantine and Muslim patterns in Art. Thus, this coincided with the Spanish essence, further transformed by the Andalusian culture. However, both currents would end up by blending and, moreover, the influx of the Mozarabic culture - which had a subsidiary to the Oriental Islamic Art. To expect more than this would be impossible. The situation of the Spanish libraries, isolated from the intellectual flow produced in post-war Europe, and his limited knowledge of the Arab world ${ }^{22}$ could only lead him to this conclusion, which takes nothing away from his efforts and enhances the reputation of his prodigious intuition.

Limited or not, nobody, inside or outside our borders, has been capable of redefining the Andalusí essence in a different fashion. Only the contributions of archaeological research in the last twenty years, together with a better knowledge of North Africa and Oriental Islam has permitted laborious advances in this field. The tragedy is that the isolation of Spanish science in this field of knowledge, and the absence of an entire generation of experts between the time of GómezMoreno in the 1930's and ourselves, cannot be resolved as quickly as one would wish.

\section{The Catálogo Monumental de España}

One of the most evident effects of the 'Regenerationist' movement which appeared in 1898 was the completion of the Catálogo Monumental de España. Its intention was absolutely clear: The return to the ideological essence of what was 'Spanish' required an appreciation of our own cultural values which had been forgotten for a long time. Principal amongst them, was our artistic heritage which lacked an inventory and was completely ignored in large areas of the country. It was in this intellectual scenario that Manuel Gómez-Moreno Martinez appeared for the first time.

Assigning the work was not easy. GómezMoreno's patron Riaño had to work against many obstacles, chief among them the youth and inexperience of the young graduate. Several other academics were putting forward their own candidates, which created further obstacles. A practice as common to the Spanish intellectual landscape now, as it was then. Finally, Gómez-Moreno was assigned the task. In addition, there was the question of which areas would be selected to be inventoried. In order to produce the catalogue,

defined our character earlier, and would do the same afterwards - seems weakened by then" (Gómez-Moreno, 1970: 121-122).

22 Gómez-Moreno knew hardly anything of the Arab world. He had visited Morocco twice - in 1921 and 1923, the latter was a more thorough trip, and he made it accompanied by students - and he had participated in the pedagogical cruise organised by the Universidad Central which, between the $14^{\text {th }}$ of June and the $1^{\text {st }}$ of August 1993, brought him to the main historical sites of the Mediterranean basin. Many lecturers and students attended this cruise. 
the correct criterion of tackling the work by provinces was followed, although these provinces did not correspond to the old historic demarcations. GómezMoreno began his task with the most difficult provinces. By virtue of their isolation, the great bulk of the archaeological richness in these provinces remained intact and unknown. In 1900, he set to work in the province of Ávila; in 1901, Salamanca; in 1903, Zamora; and in 1906, León (Gómez-Moreno, 1913 a, 1925 b, 1927 and 1967).

Nobody should be under any illusions that the production of the Catálogo Monumental de España was an easy task. This was especially true in the provinces where Gómez-Moreno carried out his work. These areas were forgotten and abandoned to centuries of neglect, with no proper roads apart from tracks worn by the hooves of horses. He had no other means of transportation to these tiny villages, but by horseback. The hotels and guesthouses of the time scarcely deserved to be referred to as such. He was faced also with the mistrust of the villagers and the initial suspicion of the local priests, who it must be said, later became his most efficient collaborators, when they had finally overcome their instinctive mistrust. They aided his search for, and study of, pieces, archaeological sites, and buildings located in the most inaccessible places. He was further hampered in his work by having to carry all his luggage, his notes, and a huge camera to make photographic plates. Did F. Sarre have to work under worse circumstances in his famous trip throughout Anatolia? (Kröger, 1995).

Its obvious that the work of Gómez-Moreno in this project, starting from a sound academic foundation, is based, before and above all, on the extensive practice and experimentation of field work, through the taking of direct detailed notes and drawings of the buildings and objects to which he was exposed. The origin of Spanish archaeology, as represented by GómezMoreno, did not intend to prove preconceived academic theories; on the contrary, it was derived from an analysis of the collected data leading to new hypothesis.

One should not underestimate, however, the role that historical and artistic methods, in their most traditional sense, played in the formation of GómezMoreno. Without this traditional base everything else would have been impossible, but - even though with the passage of time, the profile of the Spanish Islamic archaeology tends to blur certain features of these initial stages - this is one of our most clear differentiating notes. The study of the Islam of al-Andalus in its mate-

23 Leopoldo Torres Balbás was son to Rafael Torres Campos, a good friend of Francisco Giner de los Ríos, with whom he probably shared his liberal ideology.

24 Most of these articles provided the basis for his posthumous book Ciudades Hispanomusulmanas. However, due to the rial aspects was not just another facet of the History of Art, but a branch of Archaeology as it is understood today. That is to say, a science which goes far beyond the formal aspects and tries to derive extensive information from very different analysis, and to develop theoretic models.

On the other hand, his collaboration with the Spanish school of 'arabists' - the first contacts with Julián Ribera and Miguel Asín date from 1898 - and the frequent presence of his articles in the magazine Al-Andalus, should not cloud the fact that his thinking remained independent. The experience of GómezMoreno, who possessed a reasonable knowledge of the classical Arab language, was original in that he never set out with the obsessive intention of trying to prove archaeologically that which was stated in the written documentation. However, the fact that he shared the same field of studies with the great Arab specialists of the time, had to permeate many aspects common to both their activities.

There going to be a common bond between $\mathrm{M}$. Gómez-Moreno and M. Asín: the architect Leopoldo Torres Balbás. The relationship between them dated from 1910, when the future architect, then only a student, accompanied Gómez-Moreno on his excursions ${ }^{23}$.

In time, Leopoldo Torres would become Curator Architect to the Monumental Zone of High Andalusia, curator of the Alhambra of Granada, and a professor of History of Architecture in the Higher Technical School of Architecture in Madrid (García Gómez, 1960; Terrasse, 1963; Vílchez, 1988).

In the last years of his life Torres Balbás carried out an enormous research project in the form of numerous articles on Andalusí architecture and town planning. The majority of these articles were published in the $A l$ Andalus magazine, the organ of The School of Arab Studies of Madrid and Granada ${ }^{24}$. However, the Torres Balbás of this time was so preoccupied with the written sources that he ended up by producing a deformed vision of the organisation of the cities of al-Andalus, as a result of his having interpreted the source of information, often partial and disperse, in such a literal fashion.

One of the great blows to Gómez-Moreno as master to L. Torres, occurred when both were assigned by the publishers 'Plus Ultra' in Madrid to write Volumes III and IV of the aforementioned series Ars Hispaniae. These volumes were dedicated to the Islamic Art of the Iberian Peninsula. Gómez-Moreno took the third volume (See note 28), and L. Torres the fourth (Gómez-

fact that it was never finished and to the characteristics of its belated print, it never reached the same quality that the articles had attained. 
Moreno, 1951). However, the completely different conceptual way in which each of them undertook their task has had important repercussions in the history of archaeological research regarding the Islam of alAndalus. The third volume was based on the widely extensive field work experience of the master, information collected almost fifty years earlier, which would later result in its systematisation. This is why the topics were grouped chronologically.

Contrary to Gómez-Moreno, the architect chose to organise his work within a very general time frame. Thus, when referring to the Alhambra in Granada, he described it from the point of view of its architectonic units, like the Gómez-Morenos, had themselves done in their Guía de Granada many years before. Possibly because it was impossible to accomplish it by any other means, or because of the constraints of time in tackling such a difficult endeavour, the truth remains that this structure has conditioned subsequent research. That is to say that later researchers have not been able, not wanted, or not known, how to approach the monument from a purely archaeological analysis in order to outline its features at each stage. Gómez-Moreno's reaction should, therefore, come as no surprise, considering the shape the assignment had taken on, i.e. its scientific shortcomings, and its subsequent historical reverberations.

There is an unclear chapter in the story of the otherwise acute perception of Manuel GómezMoreno. Namely, his relationship with the architect Félix Hernández Giménez, one of the key figures along with Torres Balbás, of Spanish Islamic archaeology ${ }^{25}$. Félix Hernández carried out the greater part of his professional activities in Cordova. His architectonic facet was gradually overlapped by archaeology when he was appointed curator architect to the Cathedral of Cordova - the old 'Great Mosque' - and of the ruins of Medina Azahara. To the end of his days in 1975, living exclusively from his personal fortune, Félix Hernández abandoned all creative work and was exclusively dedicated to the two great achievements of the Andalusí Islam.

In the 1930's he began a whole series of works on the site of the old Cordovan Mosque - excavation of the late Roman church of San Vicente, of the minaret of Hisam I, the execution of a general surveying of the building, etc - to which we owe all our knowledge of the building with very few exceptions. Within this body of work there is one which stands out above the others due to the use of a very original method: the excavation, at a height of more than ninety meters, of

25 A later review of the figure of Félix Hernández can be found in my work Valdés (1994: xiii-xxx).

$26 \mathrm{He}$ wrote eighteen articles in total and they were published between 1936/39 and 1973. A reprint of all the articles has been published Hernández, 1997. the great minaret of 'Abd al-Rahman III which was enveloped by the bell tower of the cathedral. Félix Hernández would have never been able to carry out this archaeological activity if it had not been firstly, for the fact that Gómez-Moreno was the Director General of Fine Arts at the time, and secondly, for the agitated political situation of the Spanish Second Republic. Both these factors softened the resistance of the Cathedral Chapter to the execution of any work which would underline the unequivocally Islamic nature of the primitive building.

The research of Félix Hernández should have resulted in several important written works, but instead, never came to fruition. The reason was never clearly understood by most researchers, apart from a small circle of intimate friends. Thrilled by the results of his excavation, Félix Hernández began preparations for a book that analysed the structure of the preserved remains of the minaret, and reconstructed its original aspect. In the second part of the book, he followed the morphological sequence of the known minarets in alAndalus, and the repercussions of that immense and elegant tower in the bell towers of coeval Catalonian and Lombardic churches - his Catalonian origins had led him to become interested, in his youth, in the achievements of Christian art. Perhaps, he somehow forgot subsequent repercussions, especially those on the minarets built by the Almohad dynasty.

Finally, with the meticulousness that characterised Félix Hernández, the work was finished and submitted to Gómez-Moreno in his office at the Centre of Historical Studies. Nobody knows, for certain, the reason why Gómez-Moreno did not appreciate this work, which remained inside a drawer for many years and only saw the light of day hours before the architect's death (Gómez-Moreno, 1951). This unfortunate neglect had two palpable results: it denied experts and the general public, access to knowledge of one of the chief works of Andalusí Art, and it filled the sensitive spirit of Félix Hernández with deep bitterness, all the more so due to the profound devotion he professed to Gómez-Moreno. Hardly any of his works on the Mosque were ever published (Hernández, 1959/60), and the same can be said of what he wrote on Umayyad architecture in al-Andalus. The course of his research changed and he became mainly interested in the historical geography of al-Andalus ${ }^{26}$.

What were the reasons for Gómez-Moreno's indifference to the book on the Minaret? Was it a lack of scientific perspective? Did he underrate Félix

27 Gómez-Moreno (1949b). Subsequently, the following were printed: Gómez-Moreno, 1958, 1953 a, 1951a and the principal one 1962. 
Hernández and his outstanding scientific skills due to some unknown argument or difference of opinion? Was it a simple inability to publish his work due to external reasons? We do not know. If the omission was due to either of the first two reasons, then we should include it as a personal mistake in the negative record of Gómez-Moreno. If he had reasons other than these, they have never been clarified. Perhaps, María Elena Gómez-Moreno's silence with regard to Félix Hernández in what was her posthumous work might be of significance.

\section{HIS WORK}

M. Gómez-Moreno's research was not limited to the field of Arab archaeology. It encompassed endless fields and facets, from Prehistory ${ }^{27}$ to the Modern $\mathrm{Age}^{28}$, including the late Roman Peninsular art (Gómez-Moreno, 1952 and 1966b), Early Medieval Latin Chronicles ${ }^{29}$, Christian Medieval art (GómezMoreno, 1916, 1928b, 1928a, 1932a, 1934b, 1941b, 1946c, 1964a, 1964b, 1966a and 1965), the Spanish Renaissance (Gómez-Moreno, 1925a, 1930, 1931a, 1931b, 1933 and 1961a), Greco (Gómez-Moreno, 1943a and 1943b), the Siglo de Oro (or Spanish golden century) (Gómez-Moreno, 1926, 1945b and 1949a), Goya (Gómez-Moreno, 1935, 1946a, 1946b and 1954), and he even wrote a series of historical fictional stories grouped under the title, La Novela de España (GómezMoreno, 1928c), and a short of philosophical essay, titled the Guía de Humanidad ${ }^{30}$.

Gómez-Moreno was the subject of many tributes in the last years of his life and later. On the occasion of his death in 1970, many obituary articles were written, some of them quite dated in the information concerning his life and work. However, from the biographical

28 Gómez-Moreno (1928d; 1931c) acceptance speech delivered on the occasion of his admission to the San Fernando Royal Academy of Fine Arts. Reply by F.J. Sánchez Cantón and $1951 \mathrm{~b}$.

29 Gómez-Moreno (1932 b). Off-print including the Latin text of the Albeldense, Rotense and Profética Chronicles.

30 It was published in Madrid in 1953, although it had been written between 1936 and 1938, coinciding with the war. Its first edition was a private one - just one hundred copies and it was printed on the occasion of the golden wedding of Manuel Gómez-Moreno and his wife Elena RodríguezBolívar. The unabridged article was reprinted in GómezMoreno, 1970.

${ }^{31}$ In 1970, a monographic issue of the Boletín de la Universidad de Granada was dedicated to him. It brought together some unpublished autobiographic material, several notes for the production of his curriculum vitae, and an anthology of works relating to Gómez-Moreno that had been printed during the first half of the century. The second work - Vv. Aa. (1972) - was also due to the initiative of the University of Granada and was published after his death. This volume consisted of a complete reprint of the previous point of view, five books have been published which are worth mentioning.

The first two are of a biographical nature and are commemorative $^{31}$. The third one groups a large collection of works - some of them previously unpublished - specially dedicated to Prehistory and pre-Roman Peninsular indigenous languages (Gómez-Moreno 49b). The fourth is, above all, an anthology which contains some of his most significant writings ${ }^{32}$, and the fifth is a biography proper (Gómez-Moreno, 1995). María Elena, his eldest daughter, was the author, and it was, in fact, her latest work († 1998). Perhaps this is the most interesting work about the life and personality of the great archaeologist due to the large amount of information and details which are provided, always from a very personal point of view, which almost reflects the point of view of the master himself ${ }^{33}$.

Most of his letters of a scientific nature are still due to be published, and these should be very interesting, given the extremely wide range of Spanish and foreign figures, especially dedicated to the world of Archaeology and History of Art, with whom GómezMoreno had an epistolary relationship.

\section{Conclusions}

From this, and from some other issues which escape the chronological framework of this publication, and therefore we have not dealt with here, the conclusion to be drawn is that Gómez-Moreno is, undoubtedly, the father of Spanish Islamic archaeology and by and large in the Peninsula - i.e. prehistoric, classical and medieval archaeology. Moreover, he can be considered, with his many honourable titles, as one of the European founders of the discipline.

one, to which were added some works recently unearthed in 1970 - with the exception of that which had previously been published in the issue $\mathrm{N}^{\circ} .6$ of Cuadernos de la Alhambra.

32 Gómez-Moreno (1970). It is a truthful and painstaking anthology of his most meaningful pieces of writing, chosen by himself, with the assistance of his daughter María Elena and his pupil and friend Manuel Casamar. Not everything that was published here was previously known. Under the title Lo románico español del siglo XII (pp. 121-125), part of an extremely interesting unpublished manuscript, dealing with the Spanish Romanesque Art of the twelfth century, was included in the anthology. It can be considered as the follow-up to his book (1934b). In short, the structure of this work defines and synthesises Gómez-Moreno's scientific activity very well.

33 Part of Gómez-Moreno's letters, those exchanged with Juan de la Mata Carriazo, Professor of Medieval History in the University of Seville, were reviewed by the latter in the acceptance speech he delivered on the occasion of his admission to the Royal Academy of History: Carriazo, J. de la M. (1977). 
Nevertheless, there exist some differences between Gómez-Moreno and his colleagues from the developed Europe. The first one stems from his birth in a country that has obvious Arab cultural roots. Only Italy, amongst the countries of the Christian West, provides a partially equal example. Above and beyond any historiographical theory, the study of the Andalusí, in any of its facets, cannot be, for the Spanish - or Portuguese - people, the study of something alien to them, but the study of something that belongs to them and is well rooted in the history and life of the Iberian Peninsula. As a result, our understanding of the al-Andalus culture was based on certain preconceived ideas, which is logical for a culture that was itself defined as much by Arab Islamic culture as it was by its struggle against it.

Furthermore, the isolation and backwardness of certain areas of Spanish science, resulting from highly complex political and social circumstances, had a very negative effect on the formation of specialised libraries. The lack of elements of comparison diminished the level of accuracy, though not of their overall truthfulness, of many of the works accomplished by our specialists, including Gómez-Moreno. Needless to say their geographic isolation meant that they lacked any personal experience of other Mediterranean countries, and this did nothing but worsen the situation.

Furthermore, M. Gómez-Moreno wrote in Spanish, a language of unquestioned importance but which, unfortunately, was not one of the languages commonly used by the international scientific community. Even today, many of the Spanish scientific discoveries in this discipline remain unknown due to the failure to publish them in other widespread languages, even in versions to be distributed abroad, and to the obstinacy of non-Spanish speaking scientists not to read anything in Spanish even when they are interested in the cultural manifestations which occurred in this part of Europe.

If M. Gómez-Moreno was able to develop - in spite of the era in which he worked, his circumstances and means -, such a huge intellectual body of work, we cannot, both inside and outside Spain, but salute his merit and grant him the privileged place that our discipline reserves for its pioneers.

\section{BIBLIOGRAPHY}

Álvarez Lopera, J. (1982): "La política de bienes culturales del gobierno republicano durante la guerra civil española". Madrid

Carriazo, J. de la M. (1977): EL maestro GómezMoreno contado por él mismo. Discurso de Ingreso en la Real Academia de la Historia. Madrid.

García Gómez, M. (1960): "Leopoldo Torres Balbás". Al-Andalus, 25: 257-286.

Gómez-Moreno, M. (1897): Antigüedades cristianas de Martos. (Con inscripciones inéditas). Granada.
Gómez-Moreno, M. (1906a): "San Pedro de la Nave, iglesia visigoda". Boletín de la Sociedad Castellana de Excursiones, 1: 132-135 and 192-196. [English reprint in Architectural Review, 1909].

Gómez-Moreno, M. (1906b): "Excursión a través del Arco de Herradura". Cultura Española, 190. [Reprinted in 1970: 361-389].

Gómez-Moreno, M. (1909): "Santiago de Peñalba. Iglesia mozárabe del siglo X". Boletín de la Sociedad Castellana de Excursiones, 16: 1-12.

Gómez-Moreno, M. (1911): “Arqueta de Zamora”. La Época. [Reprinted in E. Leguina: Arquetas hispano-árabes.. Madrid. 1912: 53-65].

Gómez-Moreno, M. (1912): Diez y siete conferencias sobre arte español en la Institución Cultural Española de Buenos Aires. Buenos Aires.

Gómez-Moreno, M. (1913a): Catálogo Monumental de España. Provincia de Ávila. Madrid. (1983) Edición A. de la Morena y Ma . T. Pérez. Institución Gran Duque de Alba y Dirección General de Bellas Artes y Archivos. Madrid.

Gómez-Moreno, M. (1913b): "De arqueología mozárabe". Boletín de la Sociedad Castellana de Excursiones, 21: 89-116.

Gómez-Moreno, M. (1914): “La civilización árabe y sus monumentos en España”. In: Lecciones del VIII Curso Internacional de Expansión Comercial. Barcelona [Reprinted in Arquitectura, 1919: 305319].

Gómez-Moreno, M. (1916): Arte mudéjar toledano. In: Las obras maestras de la escultura y la decoración en España. Ed. R. Domenech. Madrid.

Gómez-Moreno, M. (1919): Iglesias mozárabes. Arte español de los siglos IX al XI. Centro de Estudios Históricos. Madrid.

Gómez-Moreno, M. (1922): Diez conferencias en la Facultad de Arquitectura de Montevideo. Montevideo.

Gómez-Moreno, M. (1924a): "La cerámica vidriada en su relación con la valenciana". In: Lectures delivered in the Faculty of Arts in Valencia. Valencia.

Gómez-Moreno, M. (1924b): Cerámica Medieval Española. Barcelona.

Gómez-Moreno, M. (1925a): "Sobre el Renacimiento en Castilla: I. Hacia Lorenzo Vázquez. II. La Capilla Real de Granada. Documentos referentes a la Capilla Real". Archivo Español de Arte y Arqueología, 1: 1-114.

Gómez-Moreno, M. (1925b): Catálogo Monumental de España. Provincia de León (1906 - 1908). Ministerio de Instrucción Pública y Bellas Artes. Madrid.

Gómez-Moreno, M. (1926): “Alonso Cano, escultor". Archivo Español de Arte y Arqueología, 1: 246-250. 
Gómez-Moreno, M. (1927): Catálogo Monumental de España: Zamora (1903 - 1905). Ministerio de Instrucción Pública y Bellas Artes. Madrid.

Gómez-Moreno, M. (1928a): "El retablo de la Catedral Vieja de Salamanca, II. Maestre Nicolás Florentino y sus obras en Salamanca". Archivo Español de Arte y Arqueología, 10: 205-212.

Gómez-Moreno, M. (1928b): Toledo: guía oficial. Toledo.

Gómez-Moreno, M. (1928c): La Novela de España. Madrid. [Reprinted in 1970: 3-8].

Gómez-Moreno, M. (1928d): Manuel Gómez-Moreno (1834 - 1918): Catálogo de la exposición de sus obras. Ateneo de Granada. Granada.

Gómez-Moreno, M. (1930): “Obras de Miguel Ángel en España". Archivo Español de Arte $y$ Arqueología, 17: 189-197.

Gómez-Moreno, M. (1931a): La escultura del Renacimiento en España. Barcelona. [German edition Munich, 1932].

Gómez-Moreno, M. (1931b): Las águilas del Renacimiento español: Bartolomé Ordóñez, Diego de Siloé, Pedro Machuca, Alonso Berruguete, 1517 - 1558. Consejo Superior de Investigaciones Científicas. Madrid.

Gómez-Moreno, M. (1931c): De Arquitectura. Discurso de ingreso en la Real Academia de Bellas Artes de San Fernando. Respuesta de F. J. Sánchez Cantón. Madrid.

Gómez-Moreno, M. (1932a): "El arca de los marfiles de San Millán de la Cogolla". Archivo Español de Arte y Arqueología, 24: 205-212.

Gómez-Moreno, M. (1932b): "Las primeras crónicas de la Reconquista: el ciclo de Alfonso III". Boletín de la Real Academia de la Historia, 100: 562-628.

Gómez-Moreno, M. (1933): "El crucifijo de Miguel Ángel". Archivo Español de Arte y Arqueología, 26: 81-84.

Gómez-Moreno, M. (1934a): "La catedral de Oviedo. (Daños y pérdidas...)". Boletín de la Real Academia de la Historia, 105: 599-610.

Gómez-Moreno, M. (1934b): El Arte Románico Español. Madrid.

Gómez-Moreno, M. (1935): "La crisis de Goya". Revista de la Biblioteca, Archivo y Museo del Ayuntamiento de Madrid, 1: 11-24.

Gómez-Moreno, M. (1940): "La loza dorada primitiva de Málaga”. Al-Andalus, 5: 383-389.

Gómez-Moreno, M. (1941a): "Capiteles árabes documentados". Al-Andalus, 6: 422-427.

Gómez-Moreno, M. (1941b): "La urna de Santo Domingo de Silos". Archivo Español de Arte, 48: 493-502.
Gómez-Moreno, M. (1943a): El Greco. Barcelona.

Gómez-Moreno, M. (1943b): El Greco. El Entierro del Conde de Orgaz. In: Obras maestras del Arte Español. Barcelona.

Gómez-Moreno, M. (1943c): “Joyas árabes de la Reina Católica”. Al-Andalus, 8: 473-475.

Gómez-Moreno, M. (1945a): "La mezquita mayor de Tudela". Príncipe de Viana, 18: 3-21.

Gómez-Moreno, M. (1945b): Unos borradores cervantescos. Barcelona.

Gómez-Moreno, M. (1946a): "El cómo y el porqué de Goya". In: Bicentenario de Don Francisco de Goya y Lucientes. Instituto de España. Madrid.

Gómez-Moreno, M. (1946b): "Los fondos de Goya". Boletín de la Real Academia de la Historia. Tirada aparte. Madrid.

Gómez-Moreno, M. (1946c): El Panteón Real de las Huelgas de Burgos. Consejo Superior de Investigaciones Científicas. Madrid.

Gómez-Moreno, M. (1947a): "El baño de la judería de Baza". Al-Andalus, 12: 151-155.

Gómez-Moreno, M. (1947b): "Historia y arte en el panteón de las Huelgas de Burgos". Arbor, 21: 397 -434 .

Gómez-Moreno, M. (1948): "Preseas reales sevillanas". Archivo Hispalense, 27-32: 191-204.

Gómez-Moreno, M. (1949a): "El viraje español". Boletín de la Real Academia de la Historia, 124: 293-304.

Gómez-Moreno, M. (1949b): Miscelánea. Historia Arte - Arqueología. Madrid.

Gómez-Moreno, M. (1951a): "Notas a las inscripciones celtibéricas de Peñalba de Villastar, de A. Tovar". Emerita, 27: 349.

Gómez-Moreno, M. (1951b): Prólogo al libor de F. Chueca: La Catedral Nueva de Salamanca. Salamanca [Reprinted in 1970: 329-333].

Gómez-Moreno, M. (1951c): Arte árabe español hasta el siglo XII. Arte mozárabe. In: Ars Hispaniae, III. Barcelona.

Gómez-Moreno, M. (1952): Perfiles de la España bárbara. Madrid.

Gómez-Moreno, M. (1953a): "El plomo de Liria". Archivo de Prehistoria Levantina, 4: 223 - 229.

Gómez-Moreno, M. (1953b): Guía de Humanidad. Madrid. [Reprinted in (1970): 421-452].

Gómez-Moreno, M. (1954): "Más obras inéditas de Goya”. Archivo Español de Arte, 105: 63-68.

Gómez-Moreno, M. (1958): Adam y la Prehistoria. Madrid.

Gómez-Moreno, M. (1961a): “Alonso Berruguete: su personalidad". Academia, 13: 11-18. [Reprinted in 1970: 217-221]. 
Gómez-Moreno, M. (1961b): El arte islámico en España y en el Magrib. In: H. Glück and E. Díez: El arte del Islam. Labor. Barcelona.

Gómez-Moreno, M. (1962): "La escritura bástulo-turdetana". Revista de Archivos, Bibliotecas y Museo, 69: 879-950.

Gómez-Moreno, M. (1964a): La gran época de la escultura española. Barcelona-Madrid-México.

Gómez-Moreno, M. (1964b): Premices de l'Art Chrétien Espagnol. In: Informations d'Histoire de l'Art.

Gómez-Moreno, M. (1965): "En torno al crucifijo de los reyes Fernando y Sancha". Informes del Instituto Central de Conservación y Restauración, 3. Madrid.

Gómez-Moreno, M. (1966a): "Primicias del arte cristiano español". Archivo Español de Arte, 39: 101159.

Gómez-Moreno, M. (1966b): Documentación goda en pizarra. Real Academia de la Historia. Madrid.

Gómez-Moreno, M. (1967): Catálogo Monumental de España. Provincia de Salamanca. Dirección general de Bellas Artes y Archivos. Madrid.

Gómez-Moreno, M. (1970): Retazos. Ideas sobre Historia, Cultura y Arte. Consejo Superior de Investigaciones Científicas. Madrid.

Gómez-Moreno, Ma .E. (1995): Manuel GómezMoreno Martínez. Fundación Ramón Areces. Madrid.

Gómez-Moreno González, M. (1888): Medina Elvira. Granada.

Gómez-Moreno González, M. (1892): Guía de Granada. Granada. [Reprinted Granada, 1982].
Hernández, F. (1959/60): "Los monumentos árabes de Córdoba: la Gran Mezquita Aljama”. Al-Mulk, 1: 139-145.

Hernández, F. (1975): El alminar de 'Abd al-Rahman III en la mezquita mayor de Córdoba, su génesis y sus repercusiones. Patronato de la Alhambra. Granada.

Hernández, F. (1997): Estudios de geografía histórica española. Ed. F. Valdés. Vol. I (Madrid, 1994); Vol. II (Madrid, 1997), Vol. III, with an index of all of them (as yet unpublished).

Kröger, J. (1995): "Friedrich Sarre (1865 bis 1945) and 'Zu Pferd mit Stift und Kamera'. Die kleinasiatische Reise von Friedrich Sarre (1895)". Museum für Islamische Kunst. Berlín.

Simonet, F.J. (1897/1903): Historia de los mozárabes de España, deducida de los mejores y más auténticos testimonios de los escritores cristianos o árabes. Madrid.

Terrasse, H. (1963): “Leopoldo Torres Balbás”. Ars Orientalis, 5: 339-354.

Torres Balbás, L. (1949): Arte Almohade. Arte Nazarí. Arte Mudéjar. In: Ars Hispaniae, IV. Madrid.

Valdés, F. (1994): “El arquitecto Félix Hernández Giménez. Apuntes para la comprensión de su obra geográfica". In: Hernández, F: Estudios de Geografía Histórica. Ed. F. Valdés. Madrid. Vol I: XIII-XXX.

Vilchez, C. (1988): La Alhambra de Leopoldo Torres Balbás. (Obras de restauración y conservación, 1923 - 1936). Granada.

Vv. Aa. (1972): Homenaje a Gómez-Moreno, 1870 1970. Universidad de Granada. 